\title{
$\infty$
}

\section{Dialektiese denke in Jacques Ellul se kritiek van "outonome" tegniek}

\author{
S.W. Vorster \\ Skool vir Chemiese en Mineraalingenieurswese \\ Potchefstroomse Universiteit vir $\mathrm{CHO}$ \\ POTCHEFSTROOM \\ E-pos: chiswv@puknet.puk.ac.za
}

\begin{abstract}
Dialectical reasoning in Jacques Ellul's critique of "autonomous" technology

Jacques Ellul (1912-1994) is one of the most influential twentieth-century philosophers of technology. His critique of the "technological system", characterized by him as an autonomous power which is on the brink of developing out of control, is original and all-encompassing

Ellul maintains that the most important features of technology are that technology is a result of sin, that it has given rise to a technological system which constitutes an "autonomous" force with the attainment of efficiency as the basis of its ethics, and that it has enslaved man. In order to counter the advance of the system, Ellul advocates a Christian form of non-violent anarchy. This form of resistance is designed to "desacralize" the technological system and is based on Ellul's exegesis of certain Biblical passages.

It is argued that Ellul tends to absolutize human freedom as well as the dialectical tension between man and technology, which he considers a precondition for human freedom. By contrasting Ellul's views with the Reformational position, it is shown that Ellul's conception of technology is inadequate, leading to an erroneous view of man's relation to technology and the meaning of technology.
\end{abstract}

\section{Inleiding}

Die lewe word vandag gekenmerk deur verstommende ontwikkelinge op die gebied van die tegniek en haas geen faset daarvan is nie reeds grondig deur die tegniek beinvloed nie. Van die mees opspraakwekkende deurbrake word na enkele weke gelate aanvaar, meestal sonder om veel aandag te skenk aan die etiese en morele kwessies ter sprake. 
Dialektiese denke in Jacques Ellul se kritiek van "outonome" tegniek

Jacques Ellul is een van die invloedrykste denkers oor die tegnologie wat die twintigste eeu opgelewer het. Sy kritiek op die "tegniese sisteem", wat hy karaktenseer as 'n outonome mag wat dreig om buite beheer te raak, is oorspronklik en omvattend. Sy werk dek 'n besonder wye veld. Peter Tijmes skryf (1992:43):

Jacques Ellul houdt zich niet aan zijn leest. Van huis uit jurist, beweegt hij zich op de terreinen van sociologie, geskiedenis, theologie, maar hij treed nooit op als filosoof. Dat is hy niet naar eigen zeggen. Toch is hij onder leden van de Amerikaanse 'Society for Philosophy and Technology' een der meest geciteerde auteurs.

Ellul is ' $n$ intellektuele versamelaar wat in sy filosofie beïnvloed is deur ' $n$ hele aantal denkkaders. Dit blyk dat hy 'n paar keer ontnugter geraak het met een denksisteem en dit dan ingeruil het vir 'n volgende, hoewel hy telkens sekere momente sy eie maak. Om die oorblyfsels van vroeëre invloede in Ellul se tegnologiekritiek op te spoor, is egter moeilik. Op die oog af wil dit voorkom of Ellul aan 'n soort intellektuele skisofrenie ly waarin teologie en sosiologie die twee pole vorm. Hy slaag daarin om sy Christenskap te verbloem as hy die "tegniese sisteem" kritiseer. Schuurman (1980:145) maak byvoorbeeld die volgende opmerking as hy Ellul se voorwaardes vir die rigting waarin oplossings vir die probleem van die tegniek gesoek moet word, behandel: "Strangely enough, Ellul never explicitly mentions his Christian convictions about life as he discusses these conditions". Schuurman (1980:125) sien Ellul as behorende tot die skool van tegniekfilosowe wat hy tipeer as die transendentaliste.

As Ellul oor die tegniek skryf, doen hy dit hoofsaaklik vanuit 'n sosiologiese perspektief. Sy uitvoerige kritiek het oor vier dekades ontwikkel deur die verskyning van verskeie werke, waarvan die drie belangrikstes 'n trilogie vorm: La Technique ou l'enjeu du siècle van 1954 (The technological society, 1964), Le système technicien van 1977 (The technological system, 1980) en Le bluff technologique van 1987 (The technological bluff, 1990). The technological system word deur baie as sy magnum opus beskou.

Uit sy werke is dit duidelik dat Ellul homself op 'n observasiepunt wil plaas wat hom, volgens sy eie oordeel, buite die "tegniese sisteem" uitlig. Hy vind dat die mens sy vryheid verloor het deur die "tegniese sisteem", maar hy word tot so 'n mate deur die "sisteem" "gehipnotiseer" dat hy onder die indruk verkeer dat hy totaal vry is. Hierdie "sisteem" beloof aan die mens 'n tegniese utopia, maar Ellul is oortuig dat dit in werklikheid besig is om te lei na 'n distopia (negatiewe utopia).

Ellul sien nie die tegniek as buite beheer nie, maar hy tipeer dit as "outonoom" (1964:133-147). Volgens Ellul is tegniek gebaseer op 'n bourgeois-kultuur, naamlik met die klem op rasionaliteit, wins en materiële gerief. Denkende, 
handelende mense is deur die "sisteem" gekorrupteer. Ellul sien dus die mens se hele eksistensie as oorheers deur 'n stryd teen die mag van die outonome "tegniese sisteem". Hy wil hierdie verlies aan menslike vryheid beveg deur die "sisteem" te "saboteer".

Die filosofie van die tegniek is die onderdeel van die kultuurfilosofie wat hom in die besonder besig hou met die tegniek as kultuurproduk. Aangesien die tegniekontwikkeling so 'n omvattende uitwerking op die mens se aardse bestaan uitoefen, is dit noodsaaklik dat 'n Reformatories-Christelike standpunt daaroor ook gehoor word. Jacques Ellul het sedert die laat veertigerjare sy profetiese stem oor die tegniek uit Frankryk laat hoor. Tog kan Ellul se insigte nie sonder meer as die outentieke Reformatoriese standpunt vertolk word nie. Op verskeie punte is daar skerp verskille met die insigte van Reformatoriese filosowe.

Dit is die doel van hierdie artikel is om deur middel van ' $n$ integrale benadering Ellul se kritiek van die tegniek te probeer verstaan aan die hand van sy sosiologiese sowel as sy teologiese uitgangspunte. In dié proses sal gepoog word om sy benadering krities te evalueer en in dié proses 'n gangbare Reformatoriese standpunt te artikuleer.

\section{Ellul se vorming as filosoof}

Jacques Ellul is op 6 Januarie 1912 in Bordeaux gebore as die enigste kind van 'n Franse moeder en 'n vader van (adellike) Servies-Italiaanse afkoms. Hy het toegang tot die Regsfakulteit te Bordeaux gekry, maar moes deeltyds werk om vir sy studies te betaal. In 1937 verdedig hy sy proefskrif suksesvol.

As student, terwyl sy vader werkloos was, word hy in 1930 bewus van Marx. Wat Marx se invloed betref, skryf hy: "Intellectually I was much influenced by Marx. ... Though I liked the analyses of Marx, including his vision of a society in which the state would have withered away, my contact with communists were poor" (Ellul, 1988:1, 2). Hy handhaaf dus 'n sekere afstand tussen hom en die kommunisme en raak mettertyd ook ontnugter met Marx self. Hy is gedurende die oorlog aktief betrokke by die Franse Weerstand en in 1944 word hy professor in Regte aan die Universiteit van Bordeaux. Vanaf 1944 tot 1946 dien hy as onderburgemeester van Bordeaux. Hy publiseer sy eerste boek in 1946. Sy tweede boek word in 1948 gepubliseer en bevat reeds die temas wat hom die res van sy lewe sou besig hou, naamlik die tegniek as die bedreiging vir menslike vryheid, en hoop as die basis van 'n Christelike etiek van vryheid. Hy raak later ook betrokke by verskeie groepe wat hulle besig hou met kernkrag- en ekologiese probleme.

As gevolg van Marx se invloed word hy bewus van Hegel en die konsep van dialektiese denke. Intellektueel bly hy sy hele lewe aangetrokke tot Marx, wat 
Dialektiese denke in Jacques Ellul se kritiek van "autonome" tegniek

hom veral drie dinge geleer het: 'n verbintenis tot rewolusie om dinge te verander, die belangrikheid van die konkrete materiële realiteit wat ons omring en sy empatie met armes en gemarginaliseerdes (Ellul, 1981:11, 12). Marx het ook Ellul se omgang met die Bybel beinvloed: "Marx changed several aspects of the way I read the Bible. I could not approach the Bible like an innocent Christian reading the text in its simplicity. Marx taught me ... that a text comes from a certain milieu, from a certain economic situation" (1981:15).

In 1932 het Ellul 'n Christen geword, maar hy het steeds aangetrokke gevoel tot die sosialisme:

It was possible to conceive of being both a Christian and a socialist. There had been a Christian socialism for years, and around 1940 a moderate socialism drew its moral teachings from the Bible. But it hardly seemed possible to go any further. From both angles the incompatibility seemed to be absolute (Ellul, 1988:3).

Nadat Ellul die Roomse Kerk in 1932-33 besoek het, raak hy ontnugter en sluit daama aan by die Franse Gereformeerde Kerk. Hy word vir 'n tyd betower deur Calvyn se strengheid en sy omvattende gebruik van die Skrif, maar raak tog ontnugter met hom (Ellul, 1981:17). Uiteindelik het hy harde woorde vir die Calvinisme, wat hy beskryf as "... that harsh, demanding, pessimistic religion with a predominance of $\sin ^{\prime \prime}(1981: 103)$.

Deur middel van medestudente ontdek Ellul werke van Karl Barth en sê daarvan:

Barth then became the second great element in my intellectual life, completely effacing Calvin. Obviously, once I began reading Karl Barth, I stopped being a Calvinist - in my understanding of the world and politics as well as, theologically, in my understanding of predestination, original sin, and the question of universal salvation. Obviously, I could no longer be a Calvinist once I understood the dialectical movement of Barth's thinking, which also brought me a clear and, I would say, free view of the Bible (Ellul, 1981:17).

Ellul pak nou 'n lang geestelike en intellektuele reis aan. Hy begin die Bybel in diepte verstaan en raak oortuig dat die Bybel 'n sekere vorm van anargisme verkondig. Hierdie siening voer hy terug na die vader van die eksistensialisme, Søren Kierkegaard (Ellul, 1988:8).

Omdat Karl Barth die behoud van politieke outoriteit verkondig, skei hulle weë Met betrekking tot sy sienings oor anargie vind hy geesgenote in die VSA Uiteindelik kom hy "tuis": "Slowly then, and on my own, not emotionally but intellectually, I arrived at my present position" (Ellul, 1988:3).

Die belangrikste neerslag van hierdie kort biografiese oorsig is dat Ellul se samestelling as filosoof belangrike elemente bevat van Marx, Calvyn, Barth, Hegel en Kierkegaard. Hierdie invloede maak dat Ellul moeilik te kategoriseer is. 
Hy is klaarblyklik 'n nonkonformis op vele terreine. In Frankryk het hy veelal onbekend en onbemind gebly en het daar ook geen onafhanklike studie oor hom verskyn nie, ook nie in Duitsland nie. Schuurman was een van die eerste filosowe wat hom met Ellul se denke oor die tegniek besig gehou het (Tijmes, 1992:44).

Ten einde Ellul se houding teenoor die tegniek te verstaan is dit vervolgens nodig om aandag te gee aan sy begrip van die tegniek

\section{Ellul se siening van die aard van tegniek}

Ellul beskou die tegniek as 'n uitvloeisel van die sondeval (1984:135). Hy stel die mens voor as 'n passiewe en onkundige slagoffer wat op 'n obskure wyse deur die tegniek beïnvloed word. Tegniek "kruip weg" en dus wil Ellul 'n konsep van die tegniek ontwikkel sodat die probleem gestalte kan kry. Hierdie model moet gebaseer wees op "reële" gegewens $(1980: 15,16)$. Die eerste stap is om tegniek te isoleer van ontelbare verbandhoudende fenomene wat nie in die "ryk" van die tegniek is nie (1980:27). Hy verklaar: "First we have to analyse the fact itself, which can be done only if we establish a concept, separating technology from its cluster of economico-political factors" (1980:29). Hy verduidelik sy metode verder soos volg: "By working out a concept we have "to grasp things as they are' and not be swept away uncritically into any random direction which our hearts happen to carry us!" (1980:32). Hy verklaar verder: "What is well known for the so-called exact sciences must also be applied to the social sciences" $(1980: 85)$. Dit is duidelik dat Ellul bang is om waardeoordele uit te spreek, waardeur hy homself dus oenskynlik plaas in die kring van die positiviste Schuurman vind 'n soortgelyke ingesteldheid in Ellul se The technological society (Schuurman, 1980:127). Ellul se beïnvloeding deur Marx is hier duidelik: "But what Marx had brought to me was a certain way of 'seeing' the political, economic and social problems - a method of interpretation, a sociology" (Winner, 1992:349).

Alhoewel Ellul by Marx geleer het om dinge reg te "sien" en te interpreteer, glo Ellul dat Marx verkeerd was om die samelewing net in terme van kapitalisme te sien. Marx het, deur sy liefde vir die tegniek, 'n deelprobleem aangesien vir die geheelprobleem, en het 'n slaaf geword van sy eie siening (1981:31).

'n Belangrike insig van Ellul is dat die mens nie soseer bedreig word deur tegniese produkte nie, maar deur die "tegniese sisteem". Ellul verklaar dat die "tegniese sisteem" bestaan uit 'n samevloeiing van die tegniese fenomeen en tegniese vooruitgang. Die tegniek het 'n "omgewing" geword en elke tegniese faktor is in die omgewing en konstitueer dit deur daarop te bestaan. Hy vervolg:

There is a system just as one can say that cancer is a system. ... One cannot conceive of technology like 'nature', as able to live on its own. ... Furthermore, man, who is to act upon this system, who is to use these technological objects, 
Diclektiese denke in Jacques Ellul se kritlek van "outonome" tegnlek

is not a man per se, an absolute subject either. He himself is incorporated in a technological society (Ellul, 1980:79, 80, 85, 87).

Vroeër het Ellul reeds die stad getipeer as 'n parasiet en die produk van Kain se rebelse sonde, wat gelei het tot 'n vertegniseerde en manipulerende gemeenskap (1970:25). Volgens Ellul (1980:18) is daar 'n spanning tussen die "tegniese sisteem" en die samelewing, net soos die "tegniese sisteem" versteurings in die natuurlike omgewing veroorsaak. Hy beskou klaarblyklik die samelewing as 'n "natuurproduk" wat self die "indringer" (die "tegniese sisteem" - 'n "kultuurproduk") wat hom bedreig, voortbring. Hierin blyk die invloed van Marx (wat Hegel navolg). Volgens Hegel kom natuur en kultuur voort uit die "idee". Marx verwerp die konsep van die "idee" en leer dat kultuur ("gees") voortkom uit materie.

In sy The technological bluff (1990) kla Ellul dat sy werke verkeerd verstaan word (1990:xiii). Hiervoor is hy tot 'n groot mate self te blameer. Nie alleen is sy twee kategorieë "la technique" en "la technologie" in die Engelssprekende wêreld oop vir misverstand nie, maar hy laat ook nie altyd duidelik blyk wanneer hy met die "sigbare" tegniek besig is en wanneer met die "onsigbare" "tegniese sisteem" nie. Sy boodskap is egter duidelik: die tegniese "sisteem" is besig om die mensdom na 'n katastofe te lei.

\section{Ellul se siening van die gevolge van tegniese ontwikkeling}

Vir Ellul is die belangrikste gevolg van die ontwikkeling van die tegniek die mens se verlies van sy vryheid. Vryheid is die mens deur die tegniek ontneem deurdat die "tegniese sisteem" die politieke magte ondersteun. Alle politieke mag word deur Ellul as duiwels gebrandmerk (1988:58). In sy In season, out of season (1982:207) kom Ellul ook byna by die punt waar hy die tegniek as sodanig demoniseer, hoewel hy waarskynlik die "tegniese sisteem" in die oog het: "God is the positive, the affirmation, the yes; and in this dialectical process, Technique is the negative, the negation (which, by the way the Bible indicates)".

Hy beskou die industriële rewolusie as maar een aspek van 'n veel wyer fenomeen, naamlik die "tegniese rewolusie" (Ellul, 1981:39). Hierdie rewolusie wil die samelewing transformeer om die beeld van die masjien te reflekteer. Die transformasie behels gewone, alledaagse dinge, wat 'n gevoel van gerustheid skep. Dit voel nie of daar iets buitengewoons besig is om te gebeur nie (Ellul, 1990:19). Die dryfveer vir die rewolusie is, volgens Ellul, 'n soeke na doeltreffendheid op alle lewensterreine (1981:33).

Hierdie soeke na die "beste metode" noem Ellul die "tegniese fenomeen". Die tegniese fenomeen word onderskei van die tegniese operasie, wat so oud is soos 
die mensdom self. Die "tegniese sisteem" is die gevolg van 'n steeds voortgaande evolusionêre proses en word gevorm deur die samesmelting van die tegniese fenomeen en idee van vooruitgang (1980:79).

Die tegniek lyk vir die moderne mens na 'n instrument van vryheid. Hierdie vryheid is egter ' $n$ illusie wat deur middel van televisiepropaganda geskep word. Mense word deur die tegniek "gehipnotiseer". Waar woorde die "hipnotiese" effek van die gedrukte boodskap teenwerk, bevorder die kort "lewe" van televisiebeelde juis so 'n "hipnose" (Ellul, 1985:142). Die propagandis van die "tegniese sisteem" se woorde is tegnies-ontwerpte woorde wat oorgawe aan die instellings van die "tegniese sisteem" moet bewerkstellig (Ellul, 1981:42). Een teken van hoop vir Ellul is dat die samelewing nog nie totaal in die "tegniese sisteem" opgeneem is nie. Dit bied geleentheid om die "sisteem" te "saboteer", maar Ellul is tog versigtig om nie ekonomiese stagnasie en die totale vernietiging van die "tegniese sisteem" te bepleit nie

Sowel die deursneemens as hoog-geskoolde mense word gefassineer deur die modeme tegniek (Ellul, 1990:323). Mense word oordonder deur 'n konvergensie van talryke tegnieke. Boonop word mense oorspoel deur 'n oormaat "inligting", maar bly nogtans in die duister oor die implikasies van tegniese besluite (1990:88). Watter sosiologiese dinamika veroorsaak hierdie verwarrende totaliserende konvergensie? Ellul glo dat dit die "sakralisering" van die "tegniese sisteem" is. (Hy gebruik die terme "heilig" en "sakraal" as teenstellings; so ook die begrippe "geloof" en "religie". Die sakrale hou verband met religie: dit is die produk van menslike gevoelens. Die heilige en geloof verbind hy aan openbaring deur God.)

'n Belangrike aspek vir Ellul is die samewerking tussen die wetenskap en die tegniek. Hy skryf:

We now have science for development's sake. By way of technique, then, science has to furnish results in economic terms. ... Science ceases to be free ... we can see this from television, in which almost every news program has a sequence of the glory of combined science and technique ... Like all deities, it has oracular power. ... The present-day ideology of science is an ideology of salvation. ... Science alone holds the future to our society. ... Science is becoming the response to everything that disquiets or troubles us (Ellul, 1990: 181-185).

Die sakrale is sowel objek van hoop as van vrees, maar op paradoksale wyse word dinge hul teenoorgesteldes. Die Bybel en die Christelike geloof word nou deur die tegniek "gedesakraliseer" waardeur die tegniek self "sakraal" word. Die verdeling van die wêreld in die "sakrale" en die "profane" oriënteer mense met betrekking tot wat hulle as absolute mag aanvaar. Gevolglik is daar vandag 'n 

na die tegniek (Ellul, 1981:100; 1985:228-229).

Opsommend kan gesê word dat die "tegniese sisteem" deur Ellul voorgehou word as 'n tiran wat die mens volledig insluit in 'n kunsmatige omgewing. As die mens die voorwaardes van die tegniek aanvaar, is die prys die verlies van persoonlike vryheid (Ellul, 1980:319). Die mens se vryheidsdrang moet hom dwing om alle sisteme te verwerp - ook die "Christelike sisteem" (Ellul, 1976:156).

Ellul het 'n beperkende siening van die mens se vryheid in Christus. Hierdie vryheid is uit genade deur Christus aan die kruis verwerf en is algemeen-geldend. Daar is geen aspek van die kosmos wat hierteen geisoleer is nie. Al sou die tegniek ook, soos Ellul beweer, 'n produk van die sonde gewees het, sou dit nogtans nie buite die domein van Christus se soenverdienste geval het nie. Dit is dus sinneloos om die "tegniese sisteem" voor te stel as 'n outonome mag. Die teenstelling tussen tegniek en vryheid is onnodig. Nogtans is dit insiggewend om Ellul se voorgestelde wyse van teenstand teen die "sisteem" na te gaan, want dit gee 'n aanduiding van onderliggende teologiese uitgangspunte.

\section{Ellul se metode om die "tegniese sisteem" te bestry}

Ellul oorweeg religie as 'n wyse waarop die "tegniese sisteem" afgetakel kan word. Religie, wat Ellul skerp onderskei van geloof, is vir hom egter 'n menslike konstruksie. Dit is 'n wyse van ontsnapping uit die realiteit. Hy stem saam met Marx dat religie "opium vir die volk" is (1981:55). Die tegniek is "n middel waarmee mense religie skep. Religie is een moontlike manifestasie van die sakrale vir die "natuurlike mens". Vir die "vertegniseerde mens", daarenteen, neem politiek die rol van religie oor. Deur hulle hoop op die politiek te plaas, kry hulle deel aan die "sakrale krag" van die tegniek, wat hulle dan die illusie van vryheid gee. Religie is volgens Ellul 'n aspek van menslike kultuurskepping en ken nie 'n transendente God nie, slegs 'n sigbare, nabye god. Ellul maak 'n radikale onderskeid tussen religie en Christelike openbaring. Die openbaring wat die Bybel gee, verwys na 'n God wat "totaal anders"' is (1981:93).

Ellul kom tot die gevolgtrekking dat menslike religiositeit die mens laat konformeer aan die eise van die tegniek, deurdat hy sy hoop op 'n sakrale, vertegniseerde politiek plaas. As tegniek dus vir sommige mense voorkom as 'n vorm van "noodlot", dan is dit omdat hulle deur religieuse vrees oorrompel is (1981:101).

In sy stryd sien Ellul geen bondgenote in menslike instellings nie, omdat hulle reeds almal "deel van die sisteem" is. Hier en daar is groepe wat die "sisteem" teengaan: die jeug, anti-kernkrag-aktiviste, eko-bewustes en vrouebewegings. Die "proletariaat" en die Derde Wêreld is reeds "geïntegreer" in die "sisteem" en dus 
nutteloos vir die "rewolusie" $(1981: 74,75)$. Watter hoop is daar nog vir die mensdom, vasgevang in die greep van die "tegniese sisteem"? Is dit moontlik om 'n opstand te bewerkstellig teen die tegniese tirannie as die tegniek self die objek geword het van menslike verwagting?

Weerstand teen die utopiese mite wat die tegniek skep, sal 'n bevestiging wees van menslike vryheid. Wat gevra word, is opstand teen die geskiedenis, teen groei en vooruitgang, teen konsumpsie en die leuen dat geluk berus op materiële goed. In ooreenstemming met Ellul se motto moet die "rewolusie" individueel geinnisieer word, maar moet dit globale konsekwensies hê $(1981: 27,81)$.

In sy soeke na 'n terrein waarop die "tegniese sisteem" doeltreffend bestry kan word, onthul Ellul se "kritiese sosiologie" drie vlakke in die struktuur van die tegniese samelewing (1981:73): Eerstens is daar die vlak van "gebeure en omstandighede". Dit is al die dinge wat die massamedia graag uitbasuin rewolusies, toesprake, verdrae, rampe. Dit is die vlak van die politiek. Aan die ander uiterste is daar die vlak van "verrykende veranderings" waar die determinante van die geskiedenis gevind word en wat alle regerings transendeer. Tussenin is daar die vlak van "stabiel-evolerende strukture" wat die epog met sy kenmerke daarstel. Dit is die vlak wat deur die tegniek gevorm word en dit is die vlak waarop rewolusionêre aksie geneem moet word. Hierdie aksie is die enigste grondslag van hoop vir Ellul.

Vir Ellul is die moontlikheid van menslike vryheid gebaseer op 'n "ander" hoop 'n hoop wat nie berus op sakralisering van die "tegniese sisteem" nie. Net só 'n hoop kan mense verlos van die verknogdheid aan die illusie van vryheid. As mense nie hierdie hoop aangryp nie, sal hulle bly vasklou aan 'n hoop veranker in een of ander aspek van die "tegniese sisteem".

Ellul se antroposentrisme veroorsaak dat sy omgang met die probleem van die tegniek wentel om wat die mens te doen staan om die "tegniese sisteem" te bestry. Hy stoot eers die tegniek tot in die "domein van Satan" en wil dan blykbaar dat die mens dit uit eie krag bestry en sodoende sy vryheid herwin. Hy sien die mens se aardse bedrywighede as slegs op homself gerig, sonder die dimensie van "bewerking en bewakıng" deur rentmeesters wat aangestel is deur God.

\section{6. 'n Etiek van vryheid}

Die etiek van die tegniek is 'n etiek van doeltreffendheid, dit wil sê primêr 'n etiek van sukses. "Goed" en "sleg" word sinonieme van "sukses" en "mislukking" respektiewelik. Alle menslike handelinge word beoordeel aan die hand van die tegniese vereiste van doeltreffendheid. Die standaarde waarvolgens beoordeel 
word, is "objektief" - die subjektiewe word verplaas na die sfeer van die feilbare. Die moontlike word die noodsaaklike (Fasching, 1981:104-109).

Ellul kom tot die gevolgtrekking dat die etiek van doeltreffendheid mense isoleer in en beperk tot die wêreld van die tegniek. Daarom is vryheid vir hom so belangrik. Vryheid is 'n voorvereiste vir 'n Christelike etiek. Ellul glo dat die afwesigheid van vryheid etiek verlaag tot blote moraliteit (1976:111).

Om 'n Christelike etiek te kan formuleer, moet ons die wil van God ken. Die Bybelse verhaal van Jona is vir Ellul die gelykenis van die oproep van individuele persone om hul rewolusionêre roeping te vervul. Volgens Ellul is die ganse mensdom uitverkies tot die ewige lewe, maar vir enkeles is daar 'n tweede, temporele uitverkiesing. Dit is ' $\mathrm{n}$ roeping om in die geskiedenis in die plek van God op te tree. Soos 'n Jona desakraliseer die sodanig geroepe Christen die geslote strukture van die "tegniese sisteem" om sodoende vryheid moontlik te maak. Vryheid is vir Ellul altyd 'n individuele daad - daar bestaan geen kollektiewe vryheid nie (Fasching, 1981:137, 142)

Ellul se gebruik van die Jona-figuur beklemtoon sy siening dat God meestal "afwesig" is. Hy verklaar dat, alhoewel God volgens die Bybel almagtig is, Hy homself beperk. Hy maak byvoorbeeld net soms van sy alomteenwoordigheid gebruik. Die mens het 'n beeld van God geskep wat meer op menslike gedagtes en logika berus as op die Bybel. God het die skepping in ses dae voltooi en op die sewende dag is Hy steeds besig om te rus. Soms kom Hy uit sy rus om vir ons 'n teug vryheid te gee en dan sê die Christene dat 'n wonderwerk gebeur het. God se gebooie is altyd tot individuele mense gerig en Hy kies spesifieke mense om 'n spesifieke taak uit te voer. God wil hê dat ons moet goed doen, maar Hy meng nie voortdurend in nie. Ons is vry om iets teen sy wil te doen (Ellul, 1988:33-45).

Ellul se godsbegrip neig na die deisstiese. Hy glo dat God die skepping grootliks aan homself oorgelaat het en dus selde ingryp. Die mens se vryheid, wat blykbaar selfs God se almag beperk, moet die mens self verwerf en moet bo alles seëvier. Hier is geen sprake van sonde en straf nie - Ellul sê trouens self dat, soos hy gevorder het in sy sosiologiese en teologiese denke, sonde vir hom 'n al hoe minder belangrike kategorie geword het. Hy verwerp die Calvinistiese siening oor straf en sonde en stem saam met Barth dat die Bybel die klem laat val op die feit dat daar universele redding vir mense is en dat sonde van minder belang is (1981:104)

Ellul verwerp die siening dat die mens (as 'n soort demiurg) met God meewerk in die proses van herskepping deur toepassing van die tegniek. God het die skepping klaar en goed geskape en daar was vir die mens genoeg om van te lewe. Adam moes werk omdat God dit beveel het, en Adam het God uit vryheid gehoorsaam, sonder bymotiewe. Die sondeval verbreek die direkte kontak tussen God en die 
mens en daar kom ook verwydering tussen die mens en die res van die skepping. Die vervreemding van die natuur bring die tegniek na vore, want die mens het nou wapens en gereedskap nodig om teen die vyandige natuur stand te hou. Vandat Adam homself afgeskei het van God, was sy vryheid nie meer gebaseer op liefde nie, maar op 'n keuse. Alles word nou met wette gereël. Die tegniek kan nie anders gesien word as 'n produk van die sondeval nie (Ellul, 1984:124-135).

Volgens Ellul vereis die Christelike etiek van vryheid dialektiese spanning tussen wêreld en evangelie; tussen doeltreffendheid as 'n etiek van die sakrale en die etiek van heiligheid as 'n lewe in Christus. Die implikasie van die Christelike etiek is dat elke daad van desakralisasie van die "tegniese sisteem" eintlik 'n daad van heiliging is.

Volgens Fasching (1981:66-72) glo Ellul dat die mens se bevryding van die "tegniese sisteem" slegs verkry kan word op 'n basis van hoop in dit wat "anders" is as die tegniese samelewing, naamlik God as die "gans Andere". Verder glo hy dat, op 'n basis van hierdie hoop, 'n anargistiese etiek van opstand die "tegniese sisteem" kan desakraliseer en dat dit 'n Christelike sosiale etiek van permanente rewolusie is, wat al waarborg vir vryheid is. Hierdie etiek ontwikkel Ellul deur middel van 'n dialektiese wisselwerking tussen sy sosiologie en sy teologie. Vir Ellul is die riglyne vir opstand en vryheid te vind in die boek Openbaring. Vir hom is dit 'n boek van rewolusionêre hoop - 'n hoop wat moontlik is al is die toekoms geblokkeer. Apokalips impliseer vir Ellul "openbaring" (dit wil sê die letterlike betekenis van die Grieks: apokalupto - om te onthul). In die apokalips is God se vryheid aan die werk in die geskiedenis, soos bemiddel deur radikale menslike hoop. Die visie van Openbaring suggereer vir Ellul 'n teologiese etiek vir Christene in die wêreld. Dit is om instrumente te wees van God se "andersheid" waardeur vryheid moontlik word.

In sy beredenering van die dualisme tussen vryheid en tegniek bly Ellul in gebreke om die "outonomie" van die tegniek as blote skyn te ontmasker. Vir Ellul kan daar dus ook geen sinvolle ontwikkeling van die tegniek plaasvind nie. Volgehoue vryheid berus op 'n permanente houding van opstand, nader omskryf as 'n verbondenheid tot "Christelike anargie".

Die belangrikste kenmerk van "Christelike anargie" is vir Ellul die verwerping van geweld (1988:11). Hy beskou anargie as die volledigste en diepste uitdrukking van sosialisme (1988:3). In sy propagering van 'n Christelike vorm van anargie, wat ook deur Barth verkondig is, verwys Ellul bytend na Calvyn wat sou gesê het dat enigiets beter is as sosiale wanorde, selfs tirannie $(1988: 9,45)$. As 'n apologeet vir geweldlose anargie, val Ellul die Kerk aan met verwysing na die geweld, veral godsdiensoorloë wat "deur die Kerk" ontketen is. Ellul verbind die tegniek baie nou met politieke en ander magstrukture. Hy eksegetiseer verskeie Bybelgedeeltes om aan te toon dat Christus nie slegs 'n vyand van magstrukture 
was nie, maar dat hy dit met veragting behandel het. Op grond van die gedeelte oor die vraag aan Jesus in verband met die belasting (Markus 12:13-17) byvoorbeeld, kom Jesus se antwoord daarop neer dat al die muntstukke in omloop die keiser se beeld dra en dus aan hom behoort. As die keiser dus sy "eiendom" vra, moet dit aan hom gegee word. Aan die ander kant, wat nie die keiser se merk dra nie, behoort nie aan hom nie. Jesus sê nie dat die belasting wettig is nie, hy toon slegs aan hoe beperk die mag van die keiser is (1988:59).

Die vraag duik onwillekeurig op: watter samelewing wil Ellul dan uiteindelik sien? Is hy ' $n$ nihilis wat alles in chaos wil sien verval? Hy verklaar byvoorbeeld dat anargiste nie aan verkiesings behoort deel te neem nie (1988:14). Dit blyk dat hy egter nie 'n anargistiese samelewing wil daarstel nie, want dan verwag hy dat daar maar net weer ' $n$ volgende manifestasie van mag na vore sal kom. Politieke (en ander vorms van) mag moet eerder teengestaan word deur klein groepies wat, hoewel nie vooraf georganiseer nie, tog 'n (lokale) sosiologiese realiteit moet wees. Hulle moet voortdurend stry vir die vryheid van ander.

Opsommend kan gesê word dat Ellul wil verhoed dat die tegniese samelewing en die "tegniese sisteem" totaal met mekaar geintegreer word. Dit wil hy op niegeweldadige wyse bewerkstellig deur die optrede van geroepe individue wat in klein groepe op plaaslike vlak optree om voortdurend die "tegniese sisteem" te "saboteer".

\section{Kritiek op Ellul se filosofie van die tegniek}

\subsection{Die rol van dialektiese denke by Ellul}

In Ellul se hantering van die sosiologie van die tegniek is dit bykans onmoontlik om enige spore van sy teologie op te merk. In sy lewensbeskouing is die persoonlike inset sentraal, maar in sy sosiologie word die persoonlike inset juis verbloem. Die sosiale feite vanwaar Ellul se sosiologie uitgaan, is saamgestel uit die bo-individuele, kollektiewe handelinge en denke van mense, met ander woorde, sy lewensvisie en sy sosiologie sluit nie naatloos by mekaar aan nie.

Ellul is innerlik verskeurd tussen sy Christenskap aan die een kant en 'n verwaterde en omvormde Marxisme aan die ander kant. Sy stryd na buite, teen die mag van die tegniek, wat hy sien as die resultaat van 'n allesoorheersende drang na doeltreffendheid, verraai ' $n$ innerlike stryd in homself. In sy sosiologie is hy reddeloos pessimisties oor die invloed van die "tegniese sisteem", maar in sy teologie is hy 'n optimis. Die bestaan van hierdie intellektuele skisotrenie en interne konflikte in sy gemoed word bevestig deur sy irrasionalisme en sy verbondenheid tot dialektiese denke 
Ellul verstaan die dinamika van die mens se interaksie met die "tegniese sisteem" op grond van dialektiese beskouings. Boli-Bennett (1980:175) identıfiseer twee dialektiese prosesse in Ellul se sosiologiese denke, naamlik tegniek/samelewing en staat/rewolusie, wat hulle differensieer op talle vlakke van die vertegniseerde sosiale struktuur. Soos by Marx is hierdie dialektiek 'n materialistiese dialektiek.

'n Hegeliaanse insig is by Ellul aanwesig in soverre die opponerende kragte onskeibaar verweef is en slegs betekenis het in verhouding tot mekaar. Die een pool impliseer altyd die ander. Ellul verskil van Hegel deurdat hy nie die opheffing van dialektiese spanning kan voorsien nie. Vir Ellul is die behoud van dialektiese spanning juis van kardinale belang om die "tegniese sisteem" te bestry. Enige sintese tussen die teenkante is vir hom ondenkbaar.

In die tegniese samelewing vertoon die tegniek vir Ellul, soos reeds gemeld, die beeld van die sakrale. Dialektiese dipole waarin die sakrale/profane skakel die teenstellings vorm, kan dus ook in sy voorstelling van die "tegniese sisteem" verwag word. Die irrasionele element in die seksuele kan byvoorbeeld beskou word as 'n teenpool vir die rasionele in die tegniek. So kan die tegniek onder sekere omstandighede deur middel van die seksuele "gedesakraliseer" word as 'n daad van opstand. Die irrasionele bied ontvlugting vir die aakligheid van 'n gemeganiseerde lewe. Mense het irrasionaliteit nodig (Ellul, 1981:54-69).

Ellul werk met 'n dialektiese konsep waarin die teenstellings mekaar op 'n deterministiese wyse opvolg - die negatiewe volg noodwendig op die positiewe en vice versa. Dit is vir hom die dinamika van die ontvouing van die geskiedenis. Ellul maak van die noodwendigheid van hierdie dialektiek 'n norm. Die alternatief is altyd die ontkenning van die bestaande en vereis dus 'n proses van ewigdurende opstand.

Vir Ellul is die behoud van dialektiese spanning die voorwaarde vir menslike vryheid. Die ontleding van Ellul se dialektiese denke is op sigself ' $n$ omvattende taak wat nie hier volledig aandag kan ontvang nie. Daar word dus volstaan met enkele voor die hand liggende voorbeelde.

\subsubsection{Spanning fussen die dele en die geheel}

Die spanning tussen die holistiese en die samestellende dele het verskillende verskyningsvorme in Ellul se filososfie. Die verskil tussen die tegniek se artefakte en die "tegniese sisteem" neig om soms die onderskeid tussen "goed" en "kwaad" te word en hou dié wesenlike gevaar vir kritici van Ellul in dat hulle hom beoordeel as "anti-tegniek".

Daar kan verder gewys word op Ellul se radikale onderskeid tussen die individuele mens en die samelewing waartoe hy behoort. Vir Ellul is die holistiese 
Dialektiese denke In Jacques Ellul se kritiek van "outonome" tegniek

eienskappe van enige entiteit radikaal verskillend van die eienskappe van die samestellende dele.

\subsubsection{Die spanning fussen optredes en hul gevolge}

Vir Ellul lei elke mensluke handeling tot 'n nuwe dialektiese spanning. Die tegniek, wat die mens moet vrymaak van die beperkinge van die werklikheid, word self ' $n$ onderdrukker. Rewolusie, wat vryheid moet verseker, lei tot nuwe onderdrukkende magstrukture. Vir Ellul is daar dus 'n radikale dubbelsinnigheid in elke menslike aksie opgesluit. Hierdie voortdurende skep van spanning is egter die basis van Ellul se begrip van menslike vryheid.

\subsubsection{Die spanning tussen 'n sosiale werklikheid en 'n geestelike werklikheid}

Die mens probeer voortdurend sy aardse ellende ontkom deur te gryp na 'n idee wat die "tegniese sisteem" transendeer. Ellul sien religie as een manifestasie van 'n poging tot ontvlugting. Hieruit kom twee dialektiese dipole na vore: eerstens wil die mens sy bekommernis oor sy aardse bestaan besweer deur sekerheid te soek in vertegniseerde sosiale strukture (kommer/gerusstelling-dialektiek). Tweedens wil hy 'n religieuse rebellie voer teen sy onmagtigheid (opstand/ onmag-dialektiek).

\subsubsection{Die oorkoelepende dialektiek in Ellul se filosofle}

Die begrondende dialektiek waaruit alle ander dialektiese teenstellings in Ellul se filosofie egter gesoek moet word, setel in sy teologie. God as die "gans Andere" is vry om sy "ja" en sy "nee" oor menslike handelinge uit te spreek. God is vry om te oordeel en te red. Die mens lewe dus in die spanning van God se absolute dialektiek. Ten einde die spanning te ontkom, maak die mens 'n aanslag op God self deur een van die dialektiese pole, naamlik God se "nee" te verwerp. Daar vind gevolglik dialektiese versplintering tot in die oneindigheid plaas. Elke menslike handeling staan in die teken van dialektiese spanning, maar Ellul maak hierdie spanning ook ' $n$ voorwaarde vir die ideaal van menslike vryheid. Hierin is weereens ' $n$ tipiese Elluliaanse dialektiek opgesluit.

Ellul vlek op deurdringende wyse die gevare van die tegniek oop. Vir hom is die gevaar nie soseer dat die tegniek die mens se vryheid aan bande lê nie, maar dat dit die noodsaaklike dialektiese prosesse in gevaar stel. Hy verabsoluteer dus die dialektiek. Hierdie verabsolutering setel weer in sy verabsolutering van menslike vryheid, wat hy direk van God se absolute vryheid wil aflei. 


\subsection{Ellul se siening van die tegniek}

'n Mens soek tevergeefs by Ellul na 'n grondige analise van die tegniek self. Ellul is tevrede met 'n oppervlakkige karikatuur van die tegniek, wat hom dan aanspoor om koorsagtig te begin soek na metodes om sy (gewaande verlore) vryheid te herwin. Hy ignoreer die prosesse wat eintlik die tegniek konstitueer: die identifikasie van 'n behoefte of begeerte, die ontwerpproses, vervaardigingsprosesse, reklame, bemarking, verspreiding en herwinning, ensovoorts. Deurdat Ellul nie die interne struktuur van die tegniek analiseer nie, aanvaar hy ook nie die tegniek as 'n histories-kulturele ontsluitingsproses nie.

As transendentalis soek Ellul die aard van en die dieper dryfvere agter tegniekontwikkeling buite die tegniek self. Hy weier egter om sekere grondliggende Bybelse waarhede te aanvaar, byvoorbeeld die kultuurmandaat (Gen. 1:28). Die gevolg is dat hy, wat sy kritiek op die tegniek betref, slegs bly vassteek by die sosiale aspek daarvan.

\subsection{Ellul se onderskatting van die mag van die sonde}

Ellul se mensbeskouing maak nie voorsiening vir die radikale en verslawende invloed van die sonde nie. Omdat hy die mens as outonoom beskou, maak hy die tegniek outonoom. Deurdat hy die indiwiduele mens en die samelewing as radikaal verskillende entiteite beskou, kan Ellul nie maklik insien dat die persoonlike geneigdheid tot sonde ook kan deurwerk tot iets soos die "tegniese samelewing" nie. Ellul eksternaliseer die sonde deur dit uit die indiwiduele sondaar oor te distilleer in allerlei tegnies-ondersteunde magstrukture wat hy dan vir sy aanvalle uitsonder. Hy oorweeg nie die moontlikheid dat strukture wat volgens Bybelse norme tot stand kom, die vryheid wat hy so naarstigtelik soek, as 'n vryheid in Christus sal verseker nie

\section{4 'n Reformatoriese siening van die tegniek}

In die Reformatoriese filosofie is 'n belangrike uitgangspunt dat die historiese voortgang van die wêreld verloop langs die lyn van skepping, sondeval, verlossing en herskepping. Dit is die heilsweg wat lei na die nuwe Jerusalem. Uit die sondeval spruit daar egter 'n tweede lyn wat getipeer kan word as 'n voortsetting van die Babel-kultuur, wat gebaseer is op die veronderstelling dat die mens outonoom is. Dit is die enigste kultuur wat Ellul oorweeg as tuiste vir die tegniek. Die tegniek is egter 'n Godgegewe sisteem van voorwetenskaplike en wetenskaplike kennis wat berus op prosedures, metodes, ontdekkings, gelowe en konvensies wat aangewend word om aanvaarbare menslike behoeftes te bevredig en om sodoende 'n God-verheerlikende kultuur te bou. Menslike behoeftes is alleen aanvaarbaar as dit die toets van Bybelse norme deurstaan. Hierdie behoeftes dui op die mens se afhanklikheid, sy onvermoë en sy onself- 

nie - slegs die genade van Christus kan hom daarteen vrywaar.

Een van die belangrikste insigte wat die Wysbegeerte van die Wetsidee gee, is dat al die mens se handelinge religieus bepaald is. Die religieuse sentrum van die mens is sy hart. As die mens se tegniese aktiwiteite dus 'n bedreiging word, moet die oorsaak daarvoor eerstens in die harte van indiwiduele mense gesoek word. Ellul soek egter die probleem van die tegniese "sisteem" in tegnies-ondersteunde magstrukture. Hulle is die produkte van die handelinge van indiwiduele mense. 'n Soeke na 'n oplossing vir die probleem van die moderne tegniek moet eerder lei na 'n ondersoek van die kondisie van die harte van hedendaagse mense. Hierdie kondisie word onder andere gekenmerk deur sekularisasie, 'n verbrokkeling van die persoonlikheid en 'n verlies aan verantwoordelikheidsin.

Reformatoriese insigte in verband met die struktuur van die aardse werklikheid lei tot norme wat ook vir die tegniek geld. Gehoorsaamheid aan die kultuurmandaat met sy bevel van "bewerk en bewaak", deur gehoorsaamheid aan al die nahistoriese aspekte van die werklikheid, is al wyse waarop die mens sy vryheid van tegniese oorheersing kan verseker. By tegniese ontwikkeling moet nie alleen die formatiewe norm (die kultuur-historiese norm) in ag geneem word nie, maar ook die talige, die sosiale, die ekonomiese, die estetiese, die juridiese, die etiese en die geloofsnorm. 'n Mens wat hierdie norme toepas, word medewerker in die herskeppingwerk van Christus, waarin die tegniek so 'n besondere rol moet speel.

\section{Gevolgtrekkings}

- Deur 'n integrale benadering waarin sowel die sosiologiese as die teologiese komponente van Ellul se tegniekfilosofie oorweeg word, is 'n meer omvattende begrip verkry van Ellul se sienings van die "tegniese sisteem" en die wyses waarop hy die "sisteem" wil bestry.

- Dit blyk dat Ellul die probleem van die "tegniese sisteem" uit 'n antroposentiese hoek benader. Hy voer aan dat God hom nie deurlopend met die skepping bemoei nie, en dus sekere mense aanwys om die bedreigings van die "tegniese sisteem" die hoof te bied. Dit moet gebeur deur 'n vorm van geweldlose Christelike anargie wat Ellul trag om op grond van Bybelse gegewens te regverdig. Hierdie "etiek van vryheid" berus op die voortdurende behoud van dialektiese spanning tussen die mens en die "tegniese sisteem". Ellul verabsoluteer nie alleen menslike vryheid nie, maar ook die dialektiek wat hierdie vryheid moet verseker.

- Ellul tipeer die tegniek verkeerdelik as 'n produk van die sonde. Hy verontagsaam die implikasies van die kultuurmandaat en die mag van die sonde in die mens se aanwending van die tegniek. Verder bly hy in gebreke 
om die struktuur van die tegniek as sodanig grondig te ontleed en hy ontmasker nooit die gewaande outonomiteit van die "tegniese sisteem" nie.

- Vanuit 'n Reformatoriese perspektief is Ellul se benadering onaanvaarbaar omdat dit nie rekening hou met die tegniek binne die volle omvang van die geopenbaarde werklikheid nie. In die besonder mis hy die insig dat die tegniek kulturele ontsluiting onder die leiding van 'n religieuse grondmotief is en dat die sin van hierdie ontsluiting slegs in Christus te vind is

\section{Bibliografie}

BOLI-BENNETT, J 1980. The absolute dialectics of Jacques Ellul. Research in Philosophy and Technology, 3:171-201

ELLUL, J. 1964. The technological society. (Transl. J. Wilkinson.) New York : Knopf

ELLUL, J 1970. The meaning of the city. (Transl. Dennis Pardee.) Grand Rapids, Mich Eerdmans

ELLUL, J. 1976. The ethics of freedom Grand Rapids, Mich. : Eerdmans.

ELLUL, J. 1980. The technological system (Transl. J. Neugroschel.) New York : Continuum.

ELLUL, J. 1981. Perspectives on our age. (Ed. William H. Vanderburg, transl. Joachim Neugroschel.) New York : The Seabury Press.

ELLUL, J. 1982 In season, out of season (Transl. Lani K Niles.) San Francisco : Harper \& Row

ELLUL, J 1984. Technique and the opening chapters of Genesis. (In Mitcham, C. \& Grote, J ed. Theology and technology. New York : University Press of America. p. 123-137.)

ELLUL, J. 1985. The humiliation of the word. (Transl. Joyce Main Hanks.) Grand Rapids, Mich. : Eerdmans.

ELLUL, J. 1988. Anarchy and Christianity. Grand Rapids, Mich. : Eerdmans

ELLUL, J. 1990. The technological bluff. (Transl. G.W. Bromiley.) Grand Rapids, Mich. Eerdmans.

FASCHING, D J. 1981. The thought of Jacques Ellul: A systematic exposition. New York The Edwin Mellen Press

SCHUURMAN, E. 1980. Technology and the future. Toronto: Wedge.

TIJMES P 1992. Jacques Ellul: Autonome techniek (In Achterhuis, H. ed. De maat van de techniek Baarn: Ambo p. 43-64.)

WINNER, L. 1992. Autonomous technology. Cambridge, Mass. : The MIT Press 